\title{
OPEN Electrical stimulation of the nucleus basalis of meynert: a systematic review of preclinical and clinical data
}

\author{
Muhammad Nazmuddin ${ }^{1 \bowtie}$, Ingrid H. C. H. M. Philippens ${ }^{2}$ \& Teus van Laar ${ }^{1}$
}

Deep brain stimulation (DBS) of the nucleus basalis of Meynert (NBM) has been clinically investigated in Alzheimer's disease (AD) and Lewy body dementia (LBD). However, the clinical effects are highly variable, which questions the suggested basic principles underlying these clinical trials. Therefore, preclinical and clinical data on the design of NBM stimulation experiments and its effects on behavioral and neurophysiological aspects are systematically reviewed here. Animal studies have shown that electrical stimulation of the NBM enhanced cognition, increased the release of acetylcholine, enhanced cerebral blood flow, released several neuroprotective factors, and facilitates plasticity of cortical and subcortical receptive fields. However, the translation of these outcomes to current clinical practice is hampered by the fact that mainly animals with an intact NBM were used, whereas most animals were stimulated unilaterally, with different stimulation paradigms for only restricted timeframes. Future animal research has to refine the NBM stimulation methods, using partially lesioned NBM nuclei, to better resemble the clinical situation in AD, and LBD. More preclinical data on the effect of stimulation of lesioned NBM should be present, before DBS of the NBM in human is explored further.

The nucleus basalis of Meynert (NBM), a cholinergic nucleus in the basal forebrain, provides extensive projections to all cortical areas and is one of the targets of deep brain stimulation (DBS) in Alzheimer's disease (AD) and both Lewy Body dementia (LBD) subtypes, including Parkinson's disease dementia (PDD) and dementia with Lewy bodies $(\mathrm{DLB})^{1-3}$. The importance of cortical cholinergic input from the NBM on cognitive processing, including attentional processes, and its defects in AD and LBD have been extensively reviewed ${ }^{4-6}$. Therefore, electrical stimulation of cholinergic NBM neurons has been hypothesized to upregulate its efferent projections and to alleviate the associated symptomatology 7,8 .

However, so far the clinical results of NBM DBS are quite poor and inconclusive. NBM DBS in one patient with PDD seemed to improve ideomotor apraxia and global cognitive functions, but these findings were obscured by additional bilateral stimulation of the subthalamic nucleus for his motor symptoms ${ }^{9,10}$. Another study showed that NBM DBS alleviated visual hallucinations in two PDD patients while effects on cognitive functioning assessed by neuropsychological testing varied in AD and DLB patients ${ }^{1-3}$.

This article provides a systematic review of the preclinical and clinical evidence of the behavioral and neurophysiological effects of the NBM DBS, in order to identify potential pitfalls and gaps in implementing the therapy in clinical practice.

\section{Results}

We retrieved 787 articles from PubMed and 567 articles from Embase based on the predefined search strategy. Overall, 1068 articles remained, after having removed duplicates and finally 128 preclinical studies and 12 clinical reports were included according to our eligibility criteria. The included animal studies were further grouped according to their primary outcomes (Fig. 1) and will be described accordingly in this section. In summary, 19 studies reported behavioral outcomes after NBM stimulation, 4 studies reported the stimulation effect on cortical acetylcholine $(\mathrm{ACh})$ release, 32 articles reported the changes of the cerebral blood flow (CBF), cerebral

${ }^{1}$ Department of Neurology, Parkinson Expertise Center, University Medical Center Groningen, University of Groningen, Hanzeplein 1 AB-51, 9700RB Groningen, The Netherlands. ${ }^{2}$ Animal Science Department, Biomedical Primate Research Centre (BPRC), P.O. Box 3306, 2280 GH Rijswijk, The Netherlands. ${ }^{\varpi}$ email: m.nazmuddin@ umcg.nl 


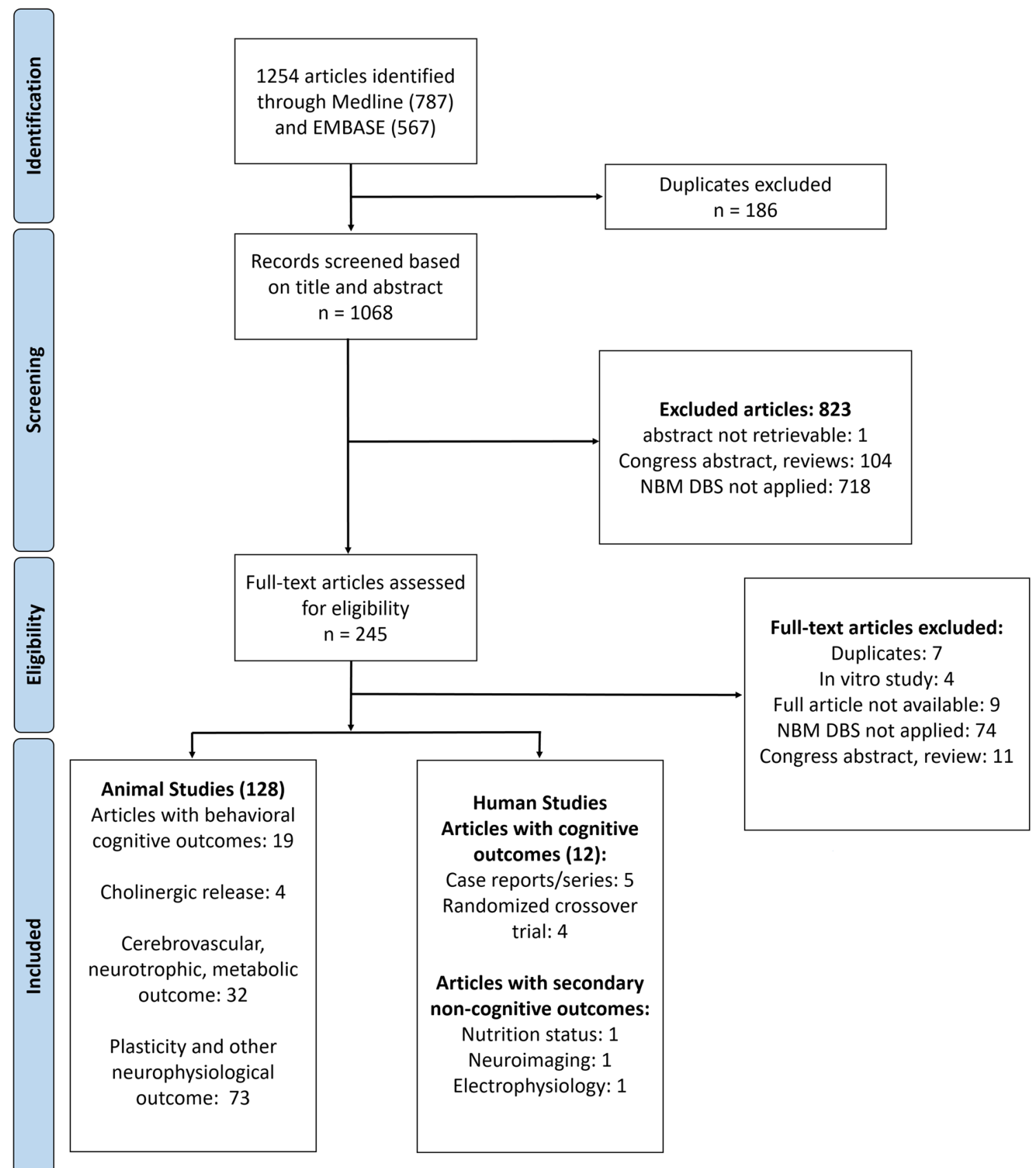

Figure 1. Diagram illustrating the search strategy of the systematic review.

metabolism, and neurotrophic release upon NBM DBS. Finally, 73 articles reported the effect of NBM DBS on neuroplasticity and cortical-subcortical connectivity based on electrophysiology measures. Finally, a comparative overview of the current clinical findings on NBM DBS is discussed.

Preclinical Evidence of NBM DBS. Effects of NBM DBS on behavioral and cognitive performance. We classified the studies investigating the effect of NBM DBS on cognitive performance into three subcategories based on the availability of a relevant control group and comparisons made in the studies as presented in Table 1.

The first group consists of six studies involving comparisons between animals with NBM DBS and sham stimulation $^{11-16}$. These articles reported in total eight independent experiments using mainly male rats, with the age varying between 6-14 weeks. NBM DBS was performed unilaterally, predominantly at the right-sided NBM. Electrical pulses were delivered either in intermittent or continuous fashion in experiments of single or multiple sessions of $20-60 \mathrm{~min}$, and varying frequencies $(10-130 \mathrm{~Hz})$ for 1 to 30 days. Cognitive tasks included the passive avoidance test, the social transmission of food preference, the tone-discrimination task, and the Morris water maze test. Endpoints focused on memory function, including encoding, consolidation, and retrieval. The significant positive effect of NBM DBS was reported on the encoding and immediate retention of memory, but 


\begin{tabular}{|c|c|c|c|c|c|c|c|c|c|}
\hline No & Author, year & $\begin{array}{l}\text { Species, strain, } \\
\text { sex }\end{array}$ & Age & Comparisons & \begin{tabular}{|l|} 
Bilateral/ \\
unilateral \\
stimulation \\
(right/left)
\end{tabular} & $\begin{array}{l}\text { Stimulation } \\
\text { parameter }\end{array}$ & Behavioral task & $\begin{array}{l}\text { Stimulation } \\
\text { timing }\end{array}$ & $\begin{array}{l}\text { Stimulation } \\
\text { duration }\end{array}$ \\
\hline \multicolumn{10}{|c|}{ I. Sham vs NBM stimulation (rodent study) } \\
\hline 1 & $\begin{array}{l}\text { Montero-Pastor } \\
\text { et al. } 2001^{11}\end{array}$ & $\begin{array}{l}\text { Rats, Wistar, } \\
\text { male }\end{array}$ & $\begin{array}{l}92.8 \\
(\mathrm{SEM}=0.66) \\
\text { days old }\end{array}$ & $\begin{array}{l}\text { Sham vs stimula- } \\
\text { tion }\end{array}$ & Unilateral (right) & $\begin{array}{l}\text { Intermittent stimula- } \\
\text { tion }(500 \mathrm{~ms} \text { with } \\
\text { electrical pulses } \\
\text { and } 500 \mathrm{~ms} \text { without } \\
\text { electrical pulses), } \\
100 \mathrm{~Hz}, 500 \mu \mathrm{s} \text {, } \\
60-90 \mu \mathrm{A}\end{array}$ & $\begin{array}{l}\text { Two-way active } \\
\text { avoidance } \\
\text { paradigm }\end{array}$ & $\begin{array}{l}\text { Immediately } \\
\text { after acquisition } \\
\text { training }\end{array}$ & $20 \mathrm{~min}$ \\
\hline 2 & $\begin{array}{l}\text { Montero-Pastor } \\
\text { et al. } 2004^{12}\end{array}$ & $\begin{array}{l}\text { Rats, Wistar, } \\
\text { male }\end{array}$ & $\begin{array}{l}97.63(\mathrm{SD}=5.52) \\
\text { days old }\end{array}$ & $\begin{array}{l}\text { Sham vs stimula- } \\
\text { tion }\end{array}$ & Unilateral (right) & $\begin{array}{l}\text { Intermittent stimula- } \\
\text { tion }(500 \mathrm{~ms} \text { with } \\
\text { electrical pulses } \\
\text { and } 500 \mathrm{~ms} \text { without } \\
\text { electrical pulses), } \\
100 \mathrm{~Hz}, 500 \mu \mathrm{s} \text {, } \\
100 \mu \mathrm{A}\end{array}$ & $\begin{array}{l}\text { Two-way active } \\
\text { avoidance } \\
\text { paradigm }\end{array}$ & $\begin{array}{l}\text { Immediately } \\
\text { before (a) or } \\
\text { after (b) acquisi- } \\
\text { tion training, } \\
\text { or before } \\
\text { 24-h-retention } \\
\text { assessment (c) }\end{array}$ & $30-45 \mathrm{~min}$ \\
\hline 3 & $\begin{array}{l}\text { Boix-Trelis et al. } \\
2006^{15}\end{array}$ & $\begin{array}{l}\text { Rats, Wistar, } \\
\text { male }\end{array}$ & $\begin{array}{l}98.23 \\
(\mathrm{SEM}=0.78) \\
\text { days old }\end{array}$ & $\begin{array}{l}\text { Sham vs stimula- } \\
\text { tion }\end{array}$ & $\begin{array}{l}\text { Unilateral (left/ } \\
\text { right) })^{*}\end{array}$ & $\begin{array}{l}\text { Intermittent stimula- } \\
\text { tion }(500 \mathrm{~ms} \text { with } \\
\text { electrical pulses } \\
\text { and } 500 \mathrm{~ms} \text { without } \\
\text { electrical pulses), } \\
100 \mathrm{~Hz}, 500 \mu \mathrm{s}, \\
100 \mu \mathrm{A}\end{array}$ & $\begin{array}{l}\text { Relational } \\
\text { odor-association } \\
\text { task-the social } \\
\text { transmission of } \\
\text { food preference } \\
\text { (STFP) }\end{array}$ & $\begin{array}{l}\text { Before acquisi- } \\
\text { tion training }\end{array}$ & $20 \mathrm{~min}$ \\
\hline 4 & Reed et al. $2011^{16}$ & Rats & N/A & $\begin{array}{l}\text { Sham vs stimula- } \\
\text { tion }\end{array}$ & Unilateral (right) & $\begin{array}{l}\text { Intermittent } \\
\text { stimulation (electri- } \\
\text { cal pulses was } \\
\text { synchronized to the } \\
\text { cue presentation), } \\
20 \text { pulses at } 100 \mathrm{~Hz}, \\
100 \mu \mathrm{s}, 120-200 \mu \mathrm{A}, \\
\text { biphasic }\end{array}$ & $\begin{array}{l}\text { Tone discrimina- } \\
\text { tion task }\end{array}$ & $\begin{array}{l}\text { During acquisi- } \\
\text { tion training }\end{array}$ & $\begin{array}{l}3 \mathrm{~h} / \text { day for } \\
20 \text { days }\end{array}$ \\
\hline 5 & Lee et al. $2016^{13}$ & $\begin{array}{l}\text { Rats, Sprague- } \\
\text { Dawley, male }\end{array}$ & 6 weeks old & $\begin{array}{l}\text { NBM-intact vs } \\
\text { NBM lesioned } \\
\text { vs NBM- } \\
\text { lesioned + elec- } \\
\text { trode implant } \\
\text { vs NBM- } \\
\text { lesioned + stimu- } \\
\text { lation }\end{array}$ & Unilateral (right) & $120 \mathrm{~Hz}, 90 \mu \mathrm{s}, 1 \mathrm{~V}$ & $\begin{array}{l}\text { Morris water } \\
\text { maze }\end{array}$ & $\begin{array}{l}\text { Before acquisi- } \\
\text { tion training }\end{array}$ & $\begin{array}{l}1 \mathrm{~h} / \text { day; } 7 \text { days } \\
\text { in total }\end{array}$ \\
\hline 6 & $\begin{array}{l}\text { Huang et al. } \\
2018^{14}\end{array}$ & $\begin{array}{l}\text { C57/BL6- } \\
\text { Tg APP/P1 } \\
\text { transgenic mice, } \\
\text { Wild type WT } \\
\text { C57BL/6 mice, } \\
\text { male }\end{array}$ & $\begin{array}{l}4,6,9 \\
12 \text { months old }\end{array}$ & $\begin{array}{l}\text { Control non- } \\
\text { surgical mice, } \\
\text { sham stimula- } \\
\text { tion, stimulation }\end{array}$ & Unilateral (left) & $\begin{array}{l}\text { Continuous } \\
\text { stimulation, } \\
(10 / 50 / 100 / 130) \mathrm{Hz} \text {, } \\
90 \mu \mathrm{s}, 1 \mathrm{~A}\end{array}$ & $\begin{array}{l}\text { Morris water } \\
\text { maze }\end{array}$ & $\begin{array}{l}\text { Before acquisi- } \\
\text { tion training }\end{array}$ & $\begin{array}{l}60 \text { min per day } \\
\text { for } 30 \text { days; } \\
60 \text { min per day } \\
\text { for } 7,14,21, \\
28 \text { days; } 60 \text { min } \\
\text { per day for } \\
21 \text { days }\end{array}$ \\
\hline \multicolumn{10}{|c|}{ II. Unsynchronized vs synchronized stimulation (rodent study) } \\
\hline 7 & $\begin{array}{l}\text { McLin III et al. } \\
2002^{17}\end{array}$ & $\begin{array}{l}\text { Rats, Wistar, } \\
\text { male }\end{array}$ & N/A & $\begin{array}{l}\text { Synchronized vs } \\
\text { unsynchronized } \\
\text { stimulation }\end{array}$ & Unilateral (right) & $\begin{array}{l}100 \mathrm{~Hz} \text { bipolar, pulse } \\
\text { width is unknown, } \\
50-100 \mu \mathrm{A}, 200 \mathrm{~ms} \\
\text { train duration }\end{array}$ & $\begin{array}{l}\text { Classical condi- } \\
\text { tioning** }\end{array}$ & \multirow{6}{*}{$\begin{array}{l}\text { During acquisi- } \\
\text { tion training }\end{array}$} & N/A \\
\hline 8 & $\begin{array}{l}\text { Weinberger et al. } \\
2006^{20}\end{array}$ & $\begin{array}{l}\text { Rats, Sprague- } \\
\text { Dawley, male }\end{array}$ & $\begin{array}{l}115(\mathrm{SD}=33) \\
\text { days old }\end{array}$ & $\begin{array}{l}\text { Weak ampli- } \\
\text { tude+ unsychro- } \\
\text { nized vs weak } \\
\text { amplitude + syn- } \\
\text { chronized } \\
\text { stimulation; } \\
\text { moderate ampli- } \\
\text { tude + unsyn- } \\
\text { chronized vs } \\
\text { moderate + syn- } \\
\text { chronized }\end{array}$ & Unilateral (right) & $\begin{array}{l}\text { bipolar, } 100 \mathrm{~Hz}, \\
200 \mu \mathrm{s}, 65.7 \pm 9.0 \\
\mu \mathrm{A} \text { (moder- } \\
\text { ate) } / 46.7 \pm 12.1 \mu \mathrm{A} \\
\text { (weak), } 200 \mathrm{~ms} \text { train } \\
\text { duration, biphasic } \\
\text { pulses }\end{array}$ & $\begin{array}{l}\text { Classical condi- } \\
\text { tioning** }\end{array}$ & & $\begin{array}{l}1-3 \text { training ses } \\
\text { sions, } \sim 4 \text { h per } \\
\text { session }\end{array}$ \\
\hline 9 & $\begin{array}{l}\text { Miasnikov et al. } \\
2006^{19}\end{array}$ & $\begin{array}{l}\text { Rats, Sprague- } \\
\text { dawley, male }\end{array}$ & $110 \pm 24$ days & $\begin{array}{l}\text { Synchronized vs } \\
\text { unsynchronized } \\
\text { stimulation }\end{array}$ & Unilateral (right) & $\begin{array}{l}\text { bipolar, } 100 \mathrm{~Hz}, \\
200 \mu \mathrm{s}, \sim 66 \mu \mathrm{A} \text {, } \\
200 \mathrm{~ms} \text { train dura- } \\
\text { tion, biphasic pulses }\end{array}$ & $\begin{array}{l}\text { Classical condi- } \\
\text { tioning }\end{array}$ & & $\begin{array}{l}1 \text { training ses- } \\
\text { sion, } \sim 4 \text { h per } \\
\text { session }\end{array}$ \\
\hline 10 & $\begin{array}{l}\text { Miasnikov et al. } \\
2009^{22}\end{array}$ & $\begin{array}{l}\text { Rats, Sprague- } \\
\text { Dawley, male }\end{array}$ & $\begin{array}{l}112(\mathrm{SD}=24) \\
\text { days old }\end{array}$ & $\begin{array}{l}\text { Synchronized vs } \\
\text { unsynchronized } \\
\text { stimulation }\end{array}$ & Unilateral (right) & $\begin{array}{l}\text { bipolar, } 100 \mathrm{~Hz}, \\
200 \mu \mathrm{s}, \sim 66 \mu \mathrm{A} \text {, } \\
200 \mathrm{~ms} \text { train dura- } \\
\text { tion, biphasic pulses }\end{array}$ & $\begin{array}{l}\text { Classical condi- } \\
\text { tioning }\end{array}$ & & $\begin{array}{l}1 \text { training ses- } \\
\text { sions, } \sim 4 \mathrm{~h} \text { per } \\
\text { session }\end{array}$ \\
\hline 11 & $\begin{array}{l}\text { Weinberger et al. } \\
2009^{18}\end{array}$ & $\begin{array}{l}\text { Rats, Sprague- } \\
\text { Dawley, male }\end{array}$ & N/A & $\begin{array}{l}\text { Synchronized vs } \\
\text { unsynchronized } \\
\text { stimulation }\end{array}$ & Unilateral (right) & $\begin{array}{l}\text { bipolar, } 100 \mathrm{~Hz} \text {, } \\
200 \mu \mathrm{s}, \sim 66 \mu \mathrm{A} \text {, } \\
200 \mathrm{~ms} \text { train dura- } \\
\text { tion, biphasic pulses }\end{array}$ & $\begin{array}{l}\text { Classical condi- } \\
\text { tioning** }\end{array}$ & & $\begin{array}{l}3 \text { training ses- } \\
\text { sions, } \sim 4 \text { h per } \\
\text { session }\end{array}$ \\
\hline 12 & $\begin{array}{l}\text { Miasnikov et al. } \\
2011^{21}\end{array}$ & $\begin{array}{l}\text { Rats, Sprague- } \\
\text { Dawley }\end{array}$ & $92(\mathrm{SD}=7)$ days & $\begin{array}{l}\text { Synchronized vs } \\
\text { unsynchronized } \\
\text { stimulation }\end{array}$ & Unilateral (right) & $\begin{array}{l}\text { bipolar, } 100 \mathrm{~Hz}, \\
200 \mu \mathrm{s}, \sim 66 \mu \mathrm{A} \text {, } \\
200 \mathrm{~ms} \text { train dura- } \\
\text { tion, biphasic pulses }\end{array}$ & $\begin{array}{l}\text { Classical condi- } \\
\text { tioning }\end{array}$ & & $\begin{array}{l}3 \text { training ses- } \\
\text { sions, } \sim 4 \text { h per } \\
\text { session }\end{array}$ \\
\hline & & & & & & & & & \\
\hline
\end{tabular}




\begin{tabular}{|c|c|c|c|c|c|c|c|c|c|}
\hline No & Author, year & $\begin{array}{l}\text { Species, strain, } \\
\text { sex }\end{array}$ & Age & Comparisons & $\begin{array}{l}\text { Bilateral/ } \\
\text { unilateral } \\
\text { stimulation } \\
\text { (right/left) }\end{array}$ & $\begin{array}{l}\text { Stimulation } \\
\text { parameter }\end{array}$ & Behavioral task & \begin{tabular}{|l} 
Stimulation \\
timing
\end{tabular} & $\begin{array}{l}\text { Stimulation } \\
\text { duration }\end{array}$ \\
\hline \multicolumn{10}{|c|}{ III. Single-group, repeated-measures study with non-human primates \& rodents } \\
\hline 13 & $\begin{array}{l}\text { Miasnikov et al. } \\
2008 \mathrm{a}^{25}\end{array}$ & $\begin{array}{l}\text { Rats, Sprague- } \\
\text { Dawley, male }\end{array}$ & $\begin{array}{l}104(\mathrm{SD}=17) \\
\text { days old }\end{array}$ & $\begin{array}{l}\text { Before vs after } \\
\text { stimulation }\end{array}$ & Unilateral (right) & $\begin{array}{l}100 \mathrm{~Hz}, 200 \mu \mathrm{s}, 66 \\
\mu \mathrm{A}, 200 \mathrm{~ms} \text { train } \\
\text { duration, biphasic } \\
\text { pulses }\end{array}$ & $\begin{array}{l}\text { Classical condi- } \\
\text { tioning** }\end{array}$ & \multirow{7}{*}{$\begin{array}{l}\text { During cognitive } \\
\text { assessment }\end{array}$} & $\begin{array}{l}1 \text { training ses- } \\
\text { sions, } \sim 4 \mathrm{~h} \text { per } \\
\text { session }\end{array}$ \\
\hline 14 & $\begin{array}{l}\text { Miasnikov et al. } \\
2008^{26}\end{array}$ & $\begin{array}{l}\text { Rats, Sprague- } \\
\text { Dawley, male }\end{array}$ & N/A & $\begin{array}{l}\text { Before vs after } \\
\text { stimulation }\end{array}$ & Unilateral (right) & $\begin{array}{l}100 \mathrm{~Hz}, 200 \mu \mathrm{s}, 66 \\
\mu \mathrm{A}, 200 \mathrm{~ms} \text { train } \\
\text { duration, biphasic } \\
\text { pulses }\end{array}$ & $\begin{array}{l}\text { Classical condi- } \\
\text { tioning** }\end{array}$ & & $\begin{array}{l}1 \text { training ses- } \\
\text { sions, } \sim 4 \mathrm{~h} \text { per } \\
\text { session }\end{array}$ \\
\hline 15 & $\begin{array}{l}\text { Avila \& Lin } \\
2014^{27}\end{array}$ & $\begin{array}{l}\text { Rats, Long- } \\
\text { Evans, male }\end{array}$ & 3-6 months & $\begin{array}{l}\text { Stimulation vs no } \\
\text { stimulation }\end{array}$ & Bilateral & $\begin{array}{l}100 \mu \mathrm{s}, 11 \text { pulses } \\
\text { with } 10 \mathrm{~ms} \text { inter- } \\
\text { stimulus interval, } \\
16-48 \mu \mathrm{A}, \text { biphasic } \\
\text { pulses }\end{array}$ & $\begin{array}{l}\text { Auditory-cued } \\
\text { discrimination } \\
\text { task }\end{array}$ & & N/A \\
\hline 16 & $\begin{array}{l}\text { Mayse et al. } \\
2015^{28}\end{array}$ & $\begin{array}{l}\text { Rats, Long- } \\
\text { Evans, male }\end{array}$ & 6 months & $\begin{array}{l}\begin{array}{l}\text { Stimulation vs no } \\
\text { stimulation }\end{array} \\
\end{array}$ & Bilateral & $\begin{array}{l}1-3 \text { pulses at } 100 \mathrm{~Hz}, \\
24-48 \mu \mathrm{A}, 100 \mu \mathrm{s}, \\
\text { biphasic pulses }\end{array}$ & $\begin{array}{l}\text { Stop no-reward } \\
\text { task }\end{array}$ & & N/A \\
\hline 17 & Liu et al. $2017^{23}$ & $\begin{array}{l}\text { Rhesus monkey } \\
\text { (M. mulata) }\end{array}$ & 6 years old & $\begin{array}{l}\text { Continuous vs } \\
\text { intermittent vs } \\
\text { no stimulation }\end{array}$ & Bilateral & $\begin{array}{l}\text { Continuous stimula- } \\
\text { tion, } 80 \mathrm{~Hz}, 100 \mu \mathrm{s} \text {, } \\
200 \mathrm{uA}, \text { biphasic } \\
\text { pulses; Intermittent } \\
\text { stimulation }(20-\mathrm{s} \\
\mathrm{ON}, 40-\mathrm{s} \text { OFF }) \\
60 \mathrm{~Hz}, 100 \mu \mathrm{s}, 200 \\
\mu \mathrm{A}, \text { biphasic pulses }\end{array}$ & $\begin{array}{l}\text { Delayed match- } \\
\text { to-sample task }\end{array}$ & & N/A \\
\hline 18 & Liu et al. $2018^{24}$ & $\begin{array}{l}\text { Rhesus monkey } \\
(\text { M. mulata }) \\
\text { male }\end{array}$ & 6 years old & $\begin{array}{l}\text { Intermittent vs } \\
\text { no stimulation }\end{array}$ & Bilateral & $\begin{array}{l}\text { Intermittent stimula- } \\
\text { tion }(20-\mathrm{s} \mathrm{ON}, 40-\mathrm{s} \\
\mathrm{OFF}), 60 \mathrm{~Hz}, 100 \\
\text { us, } 200 \mu \mathrm{A} \text {, biphasic } \\
\text { pulses }\end{array}$ & $\begin{array}{l}\text { Continuous per- } \\
\text { formance task }\end{array}$ & & N/A \\
\hline 19 & $\begin{array}{l}\text { Koulousakis } \\
\text { et al. } 2020^{29}\end{array}$ & $\begin{array}{l}\mathrm{Tg} \text { APP/P1 } \\
\text { transgenic rats, } \\
\text { male }\end{array}$ & 18 months & $\begin{array}{l}\text { Continuous vs } \\
\text { intermittent vs } \\
\text { no stimulation }\end{array}$ & Bilateral & $\begin{array}{l}\text { Intermittent stimula- } \\
\text { tion (20-s ON, } \\
40 \text {-s OFF), positive } \\
\text { monophasic pulses, } \\
100 \mu \mathrm{s}, 200 \mu \mathrm{A} \\
60 \mathrm{~Hz} \text {; continuous } \\
\text { stimulation, } 20 \mathrm{~Hz}\end{array}$ & $\begin{array}{l}\text { Modified Barnes } \\
\text { maze task }\end{array}$ & & N/A \\
\hline
\end{tabular}

Table 1. Characteristics of animal studies with information on the effect of NBM DBS on behavioral cognitive outcomes. N/A data is not available. ${ }^{*}$ left or right NBM, the number within the group was made. ${ }^{* *}$ sound of $8-\mathrm{kHz}$ tone as the conditioned stimulus, NBM stimulation as the unconditioned stimulus, and respiratory change index as the conditioned response balance.

not on the long-term retention of memory ${ }^{11,12}$. The trend of a positive effect was similarly found on the learning speed of the tone discrimination task and the spatial memory test based on the Morris water maze test.

The second subgroup consists of six studies which focused on the timing of electrical pulses to the NBM, using a classical conditioning paradigm ${ }^{17-22}$. All the experiments were performed by a single research group, using male rats of 12-17 weeks old. The DBS electrode was implanted unilaterally in the right NBM. The electrode position was verified afterwards histologically. An in-house-developed learning and memory task was used. The disruption of ongoing respiratory pattern, immediately after repetitive exposure to the sound stimuli, was considered as a behavioral marker of memory. Electrical stimulation of the NBM was able to associate the frequency of tone as the conditioned stimulus to the change of respiratory behavior. This associative behavior started $24 \mathrm{~h}$ after training and persisted for two weeks after the stimulation.

The last subgroup consists of five rodent studies and two studies with non-human primates with a singlegroup repeated-measure design ${ }^{23-29}$. The studies with rhesus macaques consisted of a longitudinal observation on the efficacy of bilateral electrical NBM stimulation with continuous and intermittent fashion delivered in different frequencies. The cognitive effects, specifically on working memory and attention, were compared. Individual-based analysis showed the significant improvement of the intermittent stimulation approach which delivered biphasic electrical pulses of $60 / 80 \mathrm{~Hz}$ to the NBM for $20 \mathrm{~s}$, interleaved with 40 -s non-stimulation. On the other hand, continuously stimulation, both at 20 and $80 \mathrm{~Hz}$, worsened the behavioral endpoints. A complementary study performed in rodents confirmed the potential benefit of intermittent stimulation for cognition, specifically related to spatial memory, as assessed by the modified Barnes maze.

Results of the quantitative analysis of studies with repetitive-measure and sham-control designs are showed by a forest plot (Fig. 2). In sham-controlled studies, NBM DBS significantly improved cognitive performance by 0.68 SMD (95\% CI 0.35-1.01). The heterogeneity between sham-controlled studies was not significant $(\mathrm{Q}=16.41$; $\left.d f=12 ; I^{2}=31.3 \% ; P=0.17\right)$. Similarly, studies with repetitive-measure design showed the positive effect of NBM DBS on animal's cognitive performance (SMD $=0.86,95 \% \mathrm{CI} 0.08-1.63)$ and non-significant between-study heterogeneity $\left(\mathrm{Q}=6.84 ; d f=4 ; I^{2}=43.6 \% ; P=0.14\right)$. The pooled effect size of all size was $0.73(95 \% \mathrm{CI} 0.43-1.04)$ and the heterogeneity among pooled studies remained non-significant $\left(\mathrm{Q}=24.3 ; d f=4 ; I^{2}=33.9 \% ; P=0.11\right)$. Funnel plot analysis indicated asymmetry of the estimated effect size, suggesting potential publication bias. Two studies 


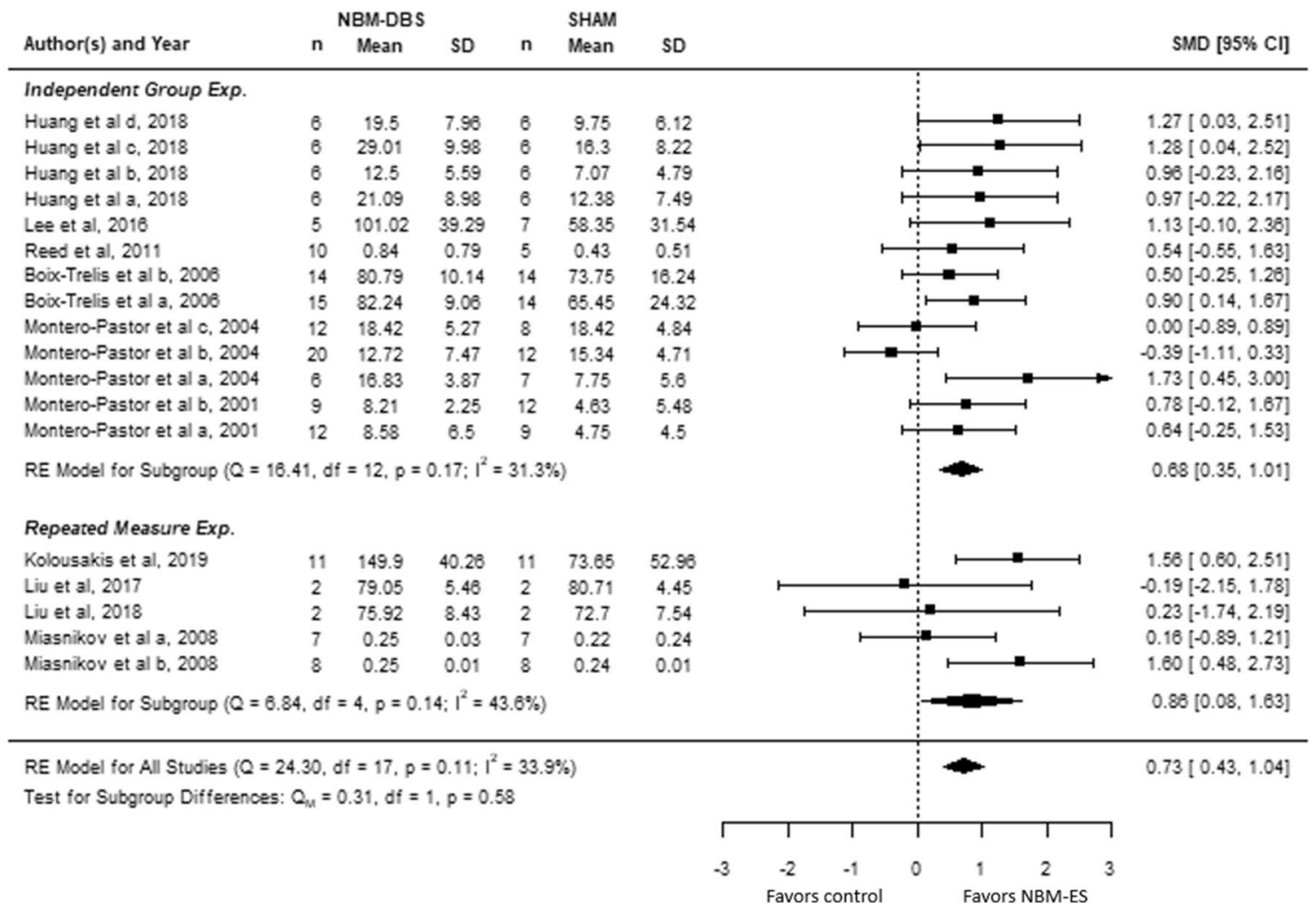

Figure 2. The forest plot summarizes the effect size and its 95\% CIs of NBM DBS on behavioral cognitive performance in studies with repeated measure design and independent-control design separately, and combined.

were subsequently imputed by trim-and-fill analysis (Supplementary Fig. 1). The positive effect of NBM DBS on cognitive performance remained significant after the correction ( $\mathrm{SMD}=0.64,95 \% \mathrm{CI} 0.33-0.94$ ).

The methodological quality of studies with behavioral outcomes was summarized in Supplementary Table 1, 2 and 3. Randomization during animal grouping was mentioned but not in sufficient details in all studies. Explanations regarding randomization and blinding during experimental procedures were also missing. However, the blinding during the outcome assessment were reported in half of the studies involving sham-stimulation group. Two studies with sham-controlled design did not report the verification of electrode placement in the $\mathrm{NBM}^{14,16}$. The reporting of stimulation parameters was found incomplete in four sham-controlled studies.

Effects of NBM DBS on cortical ACh release. Four studies in rodents investigated the effect of electrical stimulation of the NBM on the cortical release of ACh (Supplementary Table 4). All studies, except one, used anesthetized animals. All studies were uncontrolled longitudinal observations. The applied stimulation parameters varied in patterns, frequencies, pulse width, and amplitudes. The release of ACh was measured by collecting the interstitial substance of the frontoparietal cortex every 10 to $20 \mathrm{~min}$ prior to, during, and after stimulation of the NBM. Acetylcholine concentrations were analyzed using gas chromatographic-mass spectrometry or with high-performance liquid chromatography.

All studies showed that NBM DBS, both continuously and intermittently, enhanced the release of ACh in the corte $^{30-33}$. Low-frequency stimulation $(20-50 \mathrm{~Hz})$ showed a greater effect on cortical ACh release compared to high-frequency stimulation $(100-200 \mathrm{~Hz})^{33}$. However, another study reported a better effect of high-frequency compared to low-frequency stimulation when electrical pulses were delivered through a shorter burst of $10 \mathrm{~s}$ in a relatively higher stimulation amplitude $(2000 \mu \mathrm{A})$ compared to other studies ${ }^{31}$.

Effects on cerebral blood flow and metabolism. Thirty-two studies in rodents explored the effect of NBM DBS on cerebrovascular functions (Supplementary Table 5). Autoradiography, helium clearance/mass spectrometry, laser Doppler and speckle flowmetry were performed to measure changes of cerebral blood flow (CBF) and vascular structures. NBM DBS enhanced cortical and subcortical blood flow, applied either as single-burst, continuous- or phasic stimulation, with stimulation periods up to $1 \mathrm{~h}$. Especially the parenchymal vessels were dilated by activating the muscarinic and nicotinic receptors at the inner arteriole layer. Pial arteries, receiving cholinergic input from the internal carotid ganglia, remained unaffected.

Stimulation parameters, ageing, electrode positioning, and additional treatment such as sustained nicotinic subcutaneous infusion proved to modulate the vasodilatory response induced by NBM DBS ${ }^{34-37}$. The effects were amplitude-dependent ${ }^{32,35-38}$. Electrical pulses up to $100 \mathrm{~Hz}$ and train duration up to $10-30 \mathrm{~s}$ had a maximum 
effect on CBF and did not show further increase of the CBF beyond these values. All studies used a relatively long pulse width at $500 \mu \mathrm{s}$.

Effects on cortical and subcortical plasticity and connectivity. The final categories of studies in relation with NBM DBS comprises electrophysiological studies examining the NBM anatomical connectivity with other brain structures as well as scrutinizing the effect of NBM activation on subcortical and cortical activities and plasticity (Supplementary Table 6). The immediate, short-, and long-term consequences of stimulation were investigated by applying single-train and repetitive stimulation. Studies investigating the facilitatory impact of NBM DBS on cortical plasticity were typically designed by concomitantly presenting sensory cues or electrical stimulation of corresponding subcortical and cortical areas, while delivering electrical pulses to the $\mathrm{NBM}^{39-42}$. Overall, activation of NBM neurons by electrical stimulation poses deterministic excitatory and synaptic modulatory effects to the innervated brain areas, resulting in behavioral consequences, including the facilitation of learning and memory processes.

NBM DBS was able to excite its projected neurons and triggered EEG activation indicated by enhanced gamma oscillatory activity ${ }^{43-46}$. Its post-synaptic modulatory effects were shown in several studies. Burst NBM DBS, concurrently applied either with electrical stimulation to the medial as well as the lateral geniculate nucleus of the thalamus (MGN or LGN) and with tactile stimuli to facial whisker, enhanced the thalamocortical synaptic output of the corresponding projected cortices ${ }^{47-49}$. NBM DBS facilitated frequent action potentials triggered by EPSPs and inhibited persistent spontaneous hyperpolarization, which outlasted several seconds post-stimulation in the auditory cortex ${ }^{50}$. Furthermore, the amplification effect was observed to be dependent from muscarinic stimulation, and was also more pronounced with presynaptic input such as stimulation of the contralateral LGN or tactile stimuli to non-principle whisker ${ }^{49}$. The observed neuronal potentiation at single-unit recording coincided with the enhancement of evoked field potentials during electrocorticography, indicating synchronous activation of neural populations in the NBM-innervated cortices ${ }^{47,49}$. Finally, the behavioral impact of NBM DBS-elicited potentiation was demonstrated by the potentiation of vibrissae muscle contractions, induced by electrical pulses to the motor cortex, following single-burst NBM DBS ${ }^{41}$.

The facilitatory role of NBM DBS in brain plasticity was shown by the combination of NBM DBS with variable sensory cues like tone frequency, tone amplitude and visual orientation, lead to increasing neural firing, expansion of tonotopic representation in the cortical receptive field and its downstream structures, and to the promotion of task learning as a behavioral consequence ${ }^{16,39,48,51,51-57}$. The increased neural firing and tonotopic expansion are observed within $1 \mathrm{~h}$ after 40 pairing trials and gradually renormalized $24 \mathrm{~h}$ post-stimulation ${ }^{51,52}$. Another study including a high trial repetition ( 300/session) and a longer conditioning period (20 days), showed persistent receptive plasticity 20 days after the last conditioning, which disappeared at day 40 . Notably, the behavioral performance remained stable despite the renormalized tonotopic map observed at this time point ${ }^{16}$.

Clinical studies of NBM DBS. Nine primary clinical studies, including five case reports and four randomized crossover studies, involving patients with mild-to-moderate AD, PDD and DLB were identified. The description concerning subject characteristics, stimulation parameters, and the main finding of these studies are summarized in Table 2. In addition, two other studies explored the effect of NBM DBS on non-behavioral aspects, including nutritional status and brain evoked potentials. Finally, one study reported the potential structural neuroimaging correlates of NBM DBS efficacy.

The very first clinical NBM DBS experiment was reported in 1985, presenting a 71-year-old AD patient, who received unilateral NBM stimulation for nine months ${ }^{58}$. Intermittent electrical stimulation (15-s ON/12-min $\mathrm{OFF}$ ) at $50 \mathrm{~Hz}$ was applied. Cortical glucose metabolism was less reduced in the stimulated hemisphere, compared to baseline. However, cognitive functioning remained unchanged.

After more than two decades, another clinical study reported about the simultaneous bilateral placement of DBS electrodes in the NBM and STN, the standard clinical DBS target in PDD ${ }^{10}$. The patient was a 71 -year-old man with PDD, and received high-frequency stimulation of the STN for three months, before the low-frequency NBM DBS was switched ON. Turning ON the STN DBS improved motor function significantly, but hardly changed cognitive function. However, turning ON NBM DBS improved attention, alertness and drive, whereas these functions significantly worsened after switching OFF the NBM stimulator. Additional report of the same patient similarly showed remarkable improvement of his apraxic symptoms as systematically measured by the Florida apraxia screening test. This improvement was reflected when performing daily activities?.

Four randomized, controlled crossover studies comprising each six mild-to-moderate AD, PDD, or DLB did not show significant differences in cognitive performance between sham vs. NBM DBS. An open-label stimulation parameter screening based on subjective and/or objective clinical assessment was applied, either before the subjects entered the crossover study in studies with PDD and DLB or after in AD studies. The continuous low-frequency $(10-50 \mathrm{~Hz})$ stimulation was chosen except for one DLB subject who received the continuous high-frequency $(100 \mathrm{~Hz})$ stimulation. Monopolar stimulation using either of the two most distal contacts was applied. The pulse width was set between 60 and $150 \mu$ s with the amplitude ranging at 1.5 to $4.5 \mathrm{~V}$.

A longitudinal follow-up after one year in the study involving AD patients showed that the worsening of cognitive performance occurred in two patients who had poor baseline scores, while the other patients showed stable or improved performance ${ }^{1}$. The group' nutrition status after one year was unchanged ${ }^{59}$. Furthermore, secondary outcome measures with FDG PET indicated a significant positive correlation between the changes in cognitive performance and the glucose utilization around the active electrodes. Additionally, the preserved cortical thickness in several fronto-parieto-temporal regions as examined with patients' preoperative MRI was associated with stable cognitive capacity at one-year follow up. Finally, the electrophysiological effects of NBM 


\begin{tabular}{|c|c|c|c|c|c|c|c|c|}
\hline No & Author, year & Study design & $\begin{array}{l}\text { Patient diagnosis, } \\
\text { number, age }\end{array}$ & $\begin{array}{l}\text { Bilateral / } \\
\text { unilateral }\end{array}$ & $\begin{array}{l}\text { Stimulation } \\
\text { parameter }\end{array}$ & $\begin{array}{l}\text { Mentioned } \\
\text { additional } \\
\text { treatment }\end{array}$ & $\begin{array}{l}\text { Study duration } \\
\text { with active NBM } \\
\text { DBS }\end{array}$ & Results \\
\hline 1 & $\begin{array}{l}\text { Turnbull et al., } \\
1985^{58}\end{array}$ & Case report & $\mathrm{AD}, 1,74$ years & Unilateral (Left) & $\begin{array}{l}\text { Intermittent (15-s- } \\
\text { ON \& 12-min- } \\
\text { OFF); } 50 \mathrm{~Hz}, 3 \mathrm{~V} \text {, } \\
210 \mathrm{~ms}\end{array}$ & Not reported & 9 months & $\begin{array}{l}\text { the decline of the } \\
\text { cortical glucose } \\
\text { metabolism after } \\
9 \text { months was } \\
\text { smaller in the } \\
\text { ipsilateral than } \\
\text { the contralateral } \\
\text { hemisphere }\end{array}$ \\
\hline 2 & Freund et al., $2009^{10}$ & Case report & PDD, 1,71 years & Bilateral & $\begin{array}{l}\text { Continuous, } 20 \mathrm{~Hz}, \\
120 \mu \mathrm{s}, 1.0 \mathrm{~V}\end{array}$ & $\begin{array}{l}\text { DBS of the sub- } \\
\text { thalamic nucleus, } \\
\text { dopaminergic } \\
\text { medication with } \\
\text { levodopa equivalent } \\
\text { dose } 312.5 \mathrm{mg} / \text { day }\end{array}$ & 13 weeks & $\begin{array}{l}\text { scores in neuropsy- } \\
\text { chological testing } \\
\text { improved during } \\
\text { stimulation and } \\
\text { worsened after one } \\
\text { week without NBM } \\
\text { stimulation }\end{array}$ \\
\hline 3 & $\begin{array}{l}\text { Barnikol et al., } \\
2010^{9}\end{array}$ & Case report & PDD, 1,71 years & Bilateral & $\begin{array}{l}\text { Continuous, } 20 \mathrm{~Hz} \text {, } \\
120 \mu \mathrm{s}, 1.0 \mathrm{~V}\end{array}$ & $\begin{array}{l}\text { DBS of the subtha- } \\
\text { lamic nucleus }\end{array}$ & 16 months & $\begin{array}{l}\text { NBM DBS sig- } \\
\text { nificantly improved } \\
\text { apraxia symptoms }\end{array}$ \\
\hline 4 & Kuhn et al., $2015 \mathrm{a}^{1}$ & $\begin{array}{l}\text { Double-blind cross- } \\
\text { over study ( } 2 \text { weeks } \\
\text { ON-2 weeks } \\
\text { OFF), followed by } \\
48 \text {-week open label } \\
\text { study }\end{array}$ & $\mathrm{AD}, 6,57-79$ years & Bilateral & $\begin{array}{l}\text { Continu- } \\
\text { ous, } 10 / 20 \mathrm{~Hz}, \\
90-150 \mu \mathrm{s}, \\
2.0-4.5 \mathrm{~V}\end{array}$ & $\begin{array}{l}\text { Galantamine, } \\
\text { Mirtazapine, Done- } \\
\text { pezil, Lorazepam, } \\
\text { Memantine, Escit- } \\
\text { alopram (combina- } \\
\text { tion varried across } \\
\text { patients) }\end{array}$ & 50 weeks & $\begin{array}{l}\text { changes (improve- } \\
\text { ment and worsen- } \\
\text { ing) of cognitive } \\
\text { performance based } \\
\text { on neuropsycho- } \\
\text { logical testing } \\
\text { varried across } \\
\text { patients, cerebral } \\
\text { glucose metabolism } \\
\text { increased in three } \\
\text { patients }\end{array}$ \\
\hline 5 & Kuhn et al., 2015b ${ }^{94}$ & Case report & $\mathrm{AD}, 2,61 \& 67$ years & Bilateral & $\begin{array}{l}\text { Continuous, } 20 \mathrm{~Hz} \text {, } \\
\text { pulse width and } \\
\text { amplitude were not } \\
\text { reported }\end{array}$ & Not reported & $26-28$ months & $\begin{array}{l}\text { general neuropsy- } \\
\text { chological testing } \\
\text { using ADAS-Cog } \\
\text { showed stable or } \\
\text { improved results } \\
\text { while fluc- } \\
\text { tuative results were } \\
\text { observed in the } \\
\text { other tests }\end{array}$ \\
\hline 6 & $\begin{array}{l}\text { Gratwicke et al., } \\
2018^{2}\end{array}$ & $\begin{array}{l}\text { Double-blind } \\
\text { crossover study }\end{array}$ & $\begin{array}{l}\text { PDD, 6, 65.2 [10.7] } \\
\text { years }\end{array}$ & Bilateral & $\begin{array}{l}\text { Continuous, } 20 \mathrm{~Hz} \text {, } \\
60 \mu \mathrm{s}, 1.5-3 \mathrm{~V}\end{array}$ & $\begin{array}{l}\text { Dopaminergic } \\
\text { medication, } \\
\text { Rivastigmine, Cit- } \\
\text { alopram, Fesotera- } \\
\text { dine, Quetiapine, } \\
\text { Venlafaxine }\end{array}$ & 6 weeks & $\begin{array}{l}\text { cognitive per- } \\
\text { formance was } \\
\text { insignificantly dif- } \\
\text { ferent between ON } \\
\text { and OFF DBS state. } \\
\text { Statistically signifi- } \\
\text { cant improvement } \\
\text { of hallucination sub- } \\
\text { scale of the NPI was } \\
\text { observed in NBM } \\
\text { DBS state which was } \\
\text { driven by the results } \\
\text { of two patients }\end{array}$ \\
\hline 7 & $\begin{array}{l}\text { Nombela et al., } \\
2019^{62}\end{array}$ & Case report & $\begin{array}{l}\text { PD-MCI, } 1, \\
68 \text { years }\end{array}$ & Bilateral & $\begin{array}{l}\text { Continuous, } 20 \mathrm{~Hz} \text {, } \\
60 \mu \mathrm{s}, 2 \mathrm{~mA}\end{array}$ & $\begin{array}{l}\text { DBS of the internal } \\
\text { pallidum }\end{array}$ & 3 months & $\begin{array}{l}\text { Improvement in } \\
\text { spatial memory } \\
\text { test (ROCF), two } \\
\text { out of four tests } \\
\text { in executive func- } \\
\text { tion (TMT-A and } \\
\text { subscale similarities } \\
\text { of WAIS IV), and } \\
\text { a phonological } \\
\text { verbal fluency for } \\
\text { letter P, compared to } \\
\text { baseline }\end{array}$ \\
\hline 8 & $\begin{array}{l}\text { Gratwicke et al., } \\
2020^{3}\end{array}$ & $\begin{array}{l}\text { Double-blind } \\
\text { crossover study }\end{array}$ & DLB, $6,65-75$ years & Bilateral & $\begin{array}{l}\text { Continuous, } 20 \mathrm{~Hz} \text {, } \\
60 \mu \mathrm{s}, 2-3.5 \mathrm{~V}\end{array}$ & $\begin{array}{l}\text { Dopaminergic } \\
\text { medication, } \\
\text { Rivastigmine, } \\
\text { Donepezil, Cit- } \\
\text { alopram, Sertraline, } \\
\text { Amytriptylline, } \\
\text { Clonazepam, Ven- } \\
\text { lafaxine }\end{array}$ & 6 weeks & $\begin{array}{l}\text { Group-wise, no } \\
\text { significant differ- } \\
\text { ence was observed } \\
\text { between NBM and } \\
\text { sham stimulation. } \\
\text { The neuropsychi- } \\
\text { atric complains } \\
\text { reduced in 3/5 } \\
\text { patients }\end{array}$ \\
\hline 9 & $\begin{array}{l}\text { Maltête et al., } \\
2020^{61}\end{array}$ & $\begin{array}{l}\text { Double-blind } \\
\text { crossover study }\end{array}$ & DLB, $6,50-69$ years & Bilateral & $\begin{array}{l}\text { Continuous, } \\
20 / 50 / 100 \mathrm{~Hz}, \\
60-90 \mu \mathrm{s}, 2.5-3 \mathrm{~V}\end{array}$ & Rivastigmine & 3 months & $\begin{array}{l}\text { No significant } \\
\text { difference on cogni- } \\
\text { tive performance } \\
\text { between sham } \\
\text { versus NBM DBS }\end{array}$ \\
\hline
\end{tabular}

Table 2. Characteristics and results of NBM DBS clinical studies reporting cognitive outcomes. ADAS-Cog Alzheimer's Disease Assessment Scale Cognitive Subscale, ROCF Rey-Osterrieth Complex Figure, TMT-A Trail Making Test A, WAIS IV Wechsler Adult Intelligence Scale IV. 


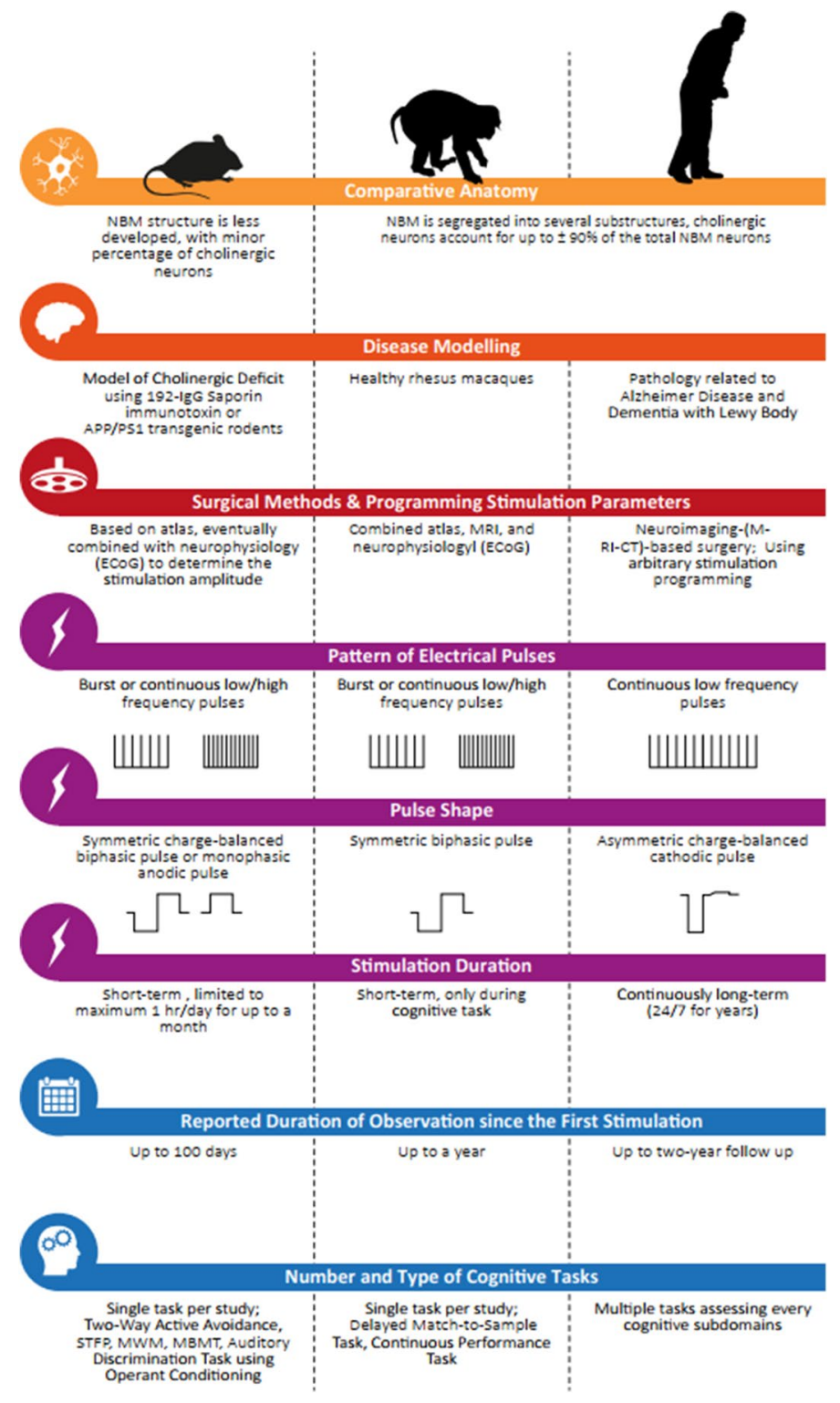

Figure 3. Differences in the anatomy of cholinergic basal forebrain, the presence of AD/LBD pathology, surgical and stimulation methodology, duration of stimulation and observation, and cognitive measure approach between rodent, non-human primate, and clinical studies investigating the cognitive efficacy of NBM DBS.

DBS were studied by means of evoked potentials, using the passive auditory oddball paradigm. This study showed normalization of P50-N100 after NBM DBS ${ }^{60}$.

Three other crossover studies on NBM DBS were applied in DLB or PDD. Decreased neuropsychiatric inventory (NPI) scores, which was mainly driven by a decrease of visual hallucination, apathy and caregiver distress, were observed in two PDD and three DLB subjects ${ }^{2,3}$. Additionally, significant improvement of functional connectivity in the frontoparietal and default mode network in DLB subjects were noticed ${ }^{3}$. In another study, alleviation of motor symptoms and increased metabolic activity at the superior lingual gyrus following NBM DBS was shown while cognitive function remained unchanged ${ }^{61}$.

Finally, a recent case report showed the use of a novel DBS system in one PD patient with mild cognitive impairment (PD-MCI), providing simultaneous high-frequency stimulation of the internal part of the globus pallidus (GPi) and low-frequency stimulation of the NBM, via a single eight-contact lead. However, the cognitive effect of bilateral low frequency stimulation of the NBM, in addition to stimulation of the GPi, was inconclusive ${ }^{62}$.

\section{Discussion}

This study systematically reviewed and compared the current preclinical and clinical evidence on the effects of electrical NBM stimulation, including behavioral and neurophysiological effects. Here we will discuss the major findings as illustrated in Fig. 3 and the consequences for future clinical research on NBM DBS. 
Our meta-analysis identified the overall positive effect of NBM DBS on attention, working memory, learning and long-term memory, using both negative and positive reinforcement. The positive behavioral impact is supported by the potential of NBM stimulation to improve cortical and subcortical plasticity, to induce cortical vasodilation and to enhance the release of $\mathrm{ACh}$ and neuroprotective factors, without necessarily increasing the metabolic activity of the projecting area. This means that NBM DBS has a great potential, which is very much dependent from the stimulation paradigms and surgical approaches.

This review showed that intrinsic animal characteristics such as age, baseline cognitive capacity and the intactness of the NBM directly correlate to the cognitive benefit of NBM stimulation. Similarly, NBM DBS studies in $\mathrm{AD}$ patients indicated a better effect in younger patients, likely reflecting the more intact cholinergic functioning in this subgroup. This finding is in accordance with other studies showing that the cholinergic treatment response is predicted by the degree of functional cholinergic integrity, based on resting state functional MRI and cholinergic PET scans in patients with $\mathrm{MCI}^{63,64}$. However, another recent study in early AD patients did not find a significant correlation between the basal forebrain volume and the response of acetylcholinesterase inhibitor after six months of treatment ${ }^{65}$. So, more data is needed to solve this issue, because this should be the basis of selection for future clinical studies with NBM DBS. Possibly only patients at the MCI stage are suitable for NBM DBS, but this is unclear at this moment.

In animal studies, incorporation of intraoperative electrocorticography (ECoG) to observe cortical desynchronization elicited by NBM DBS leads to precise electrode implantation and improves efficacy in cognition and neuroplasticity ${ }^{18,24,25}$. On the other hand, the current surgical approach in clinical studies still depends on the stereotactic surgical map and high-resolution structural imaging in their targeting protocol. Meanwhile, the use of ECoG within clinical DBS studies is emerging, not only merely for neurophysiological research in the intraoperative setting, but also as a neural-machine interface for close-loop DBS system in epilepsy and movement disorders ${ }^{66-71}$. In the context of NBM DBS, ECoG would be helpful to assist in the stereotactic targeting, and also to guide the optimization of stimulation parameters based on the cortical desynchronization. ECoG, in combination with behavioral monitoring, can be used to monitor the chronic effects of NBM DBS and to guide the refinement of stimulation parameters. Additionally, it will also lead to ECoG-based biomarkers which can be integrated in closed-loop technology. Quantitative EEG to assess oscillatory changes in cortical areas might be an alternative for ECoG, to refine stimulation parameters and the steering of electrodes ${ }^{67,72,73}$.

The efficacy of NBM DBS is primarily dependent from optimal stimulation parameters. Current clinical studies used continuous low-frequency stimulation $(10-50 \mathrm{~Hz})$ to stimulate the NBM. The low frequency is based on the observed firing rates of the NBM in rodents during movements, and on the simplified hypothesis that low-frequency pulses exerts excitatory effects, while high-frequency pulses would have inhibitory effects ${ }^{10,74}$. Current understanding of the DBS-related mechanisms of action however points beyond this simplified excitatoryinhibitory hypothesis ${ }^{75,76}$. Another issue is related to the continuity of stimulation; intermittent vs. continuous stimulation. Recent animal studies in healthy rhesus macaques and APP/PS1 transgenic rats that systematically compared the cognitive effects of continuous versus intermittent burst of $20-\mathrm{s}, 60-\mathrm{Hz}, \mathrm{ON}$ and 40 -s OFF stimulation indicated the superior benefit of the intermittent stimulation on working memory ${ }^{23,24}$. Additionally, the majority of rodent studies of NBM DBS applied the micro-burst (in $500 \mathrm{~ms}-\mathrm{ON}$ and 500 -ms-OFF) stimulation.

The translational interpretation of NBM-related animal data should be made with caution, due to several issues. The first issue is related to the anatomical difference of the cholinergic nuclei between rodents and primates, including the balance between cholinergic and non-cholinergic neurons in the basal forebrain. Also, the difference in the structural segregation and the cortical projections from NBM subdivisions between rodents and human has significant consequences for the cognitive and behavioral effects ${ }^{77-79}$. For example, in human, the anterior NBM projects its neurons more to the frontal lobe whereas the posterior part innervates the temporal region $^{80,81}$. Meanwhile in rodent, frontocaudal organization determines the distinct cortical layer projections ${ }^{82}$. Furthermore, several studies pointed specifically that the volume loss of the posterior NBM is associated with decreased global cognitive capacity and memory retrieval in $\mathrm{AD}$ and $\mathrm{PD}$ patients ${ }^{83,84}$. Thus, where the electrode is placed within the NBM becomes crucial in driving the clinical outcomes. Considering the rostrocaudal elongation and projection of the NBM, one may propose to stereotactically target the NBM periorbitally to provide as many DBS contacts as possible to the whole NBM.

An important issue is that animal studies are based on relatively short stimulation periods in contrast with the continuous 24-h stimulation in clinical studies. Typically, the electrical pulses were applied prior to, during, or after behavioral training. None of the animal studies systematically compared the effect of different durations of stimulation and the timing of stimulation within $24 \mathrm{~h}$. The timing seems to be very important, as shown by the fact that if NBM DBS is applied during sleep, the normal sleep wake cycle is disrupted, which is important for the physiological process of learning and memory ${ }^{85,86}$.

Another translational obstacle is that most preclinical data were derived from unilateral stimulations of nondiseased rodents, with intact basal forebrains. Only three studies with rodents addressed this issue. The first one used intraventricular 192-IgG Saporin infusion to lesion the NBM, which was stimulated thereafter ${ }^{13}$, while the others used transgenic mouse and rat models of AD, overexpressing Amyloid- $\beta$ precursor and Presenilin 1 protein $(\mathrm{APP} / \mathrm{PS} 1)^{14,29}$. However, only the PS1 study conducted bilateral NBM stimulation, whereas no systematic comparison between unilateral versus bilateral stimulation was reported. This is an important flaw, because of the lateralization of the basal forebrain and the NBM function in attentional processing ${ }^{87-89}$.

Furthermore, several animal studies applied stimulation amplitudes that either hardly induced neuronal excitability $( \pm 1 \mu \mathrm{A})$ or likely induced tissue damage $(1 \mathrm{~mA})$, rather than stimulating neuronal tissues. Additionally, monophasic stimulation was mostly used, instead of the biphasic pulses that are normally used in clinical NBM DBS.

Finally, several animal studies reported incomplete stimulation parameters, without mentioning pulse length, frequency or pulse shape, which have great impact on the final outcomes ${ }^{90-95}$. Despite the methodological 
problems to translate the current preclinical evidence into clinical practice, at least three clinical trials are currently actively recruiting participants with AD or LBD (clinicaltrials.gov, NCT04571112, NCT02589925, NCT03959124).

This review shows that more preclinical data are needed to design proper future clinical studies. We think that the rather poor clinical effects of NBM DBS so far are related to suboptimal selection of patients and to suboptimal stimulation paradigms. More preclinical evidence is needed to optimize NBM DBS clinically. Animal experiments should focus on the relationship between partially lesioned NBM and the effect of NBM stimulation, in order to guide clinical patient selection. The addition of in vivo cholinergic imaging might contribute to translate the findings into clinical practice, as well as the combination with pharmacological interventions. Last but not least refined preclinical protocols, focusing on the variety of stimulation parameters, should result in recommendations for the clinical setting, whereas electrocortical recordings or deep brain sensing of f.i. local field potentials should be integrated in these protocols.

\section{Conclusion}

In summary, our preclinical systematic review shows the potential benefits of NBM DBS. However, these positive effects should be cautiously interpreted, due to substantial pitfalls in the design, conduct, and reporting of these studies so far. The reporting of the applied NBM stimulation paradigms in animal models should be standardized to increase the comparability and utility.

In our opinion NBM DBS research should focus first on proper preclinical studies, before starting new clinical trials on NBM DBS. We have to justify new trials in this vulnerable target population for NBM DBS, in order to improve the currently rather poor clinical effects of NBM DBS.

\section{Methods}

Study design. The systematic review of the animal studies was conducted in accordance to methods and guidelines from the Systematic Review Centre for Laboratory Animal Experimentation (SYRCLE) ${ }^{96,97}$. The protocol of the systematic review was registered in the Collaborative Approach to Meta-Analysis and Review of Animal Data from Experimental Studies (CAMARADES) database. Additionally, we reviewed separately all available clinical literature in order to compare the findings in the animal studies.

Search strategy. Literature search was performed in two electronic databases, MEDLINE and Embase. No time restriction was applied, and all available literature up to November 2020 was reviewed. Two search components were combined: electrical stimulation and the NBM, as described in Supplementary File. Considering that rodent studies often referred the NBM structure to its broader anatomical term, the basal forebrain due to the inherently indistinctive and less-differentiated nature of this structure in rodents than in primates, we therefore included the term "basal forebrain" in our search strategy $y^{77,7}$. However, articles which clearly specified the basal forebrain structure as non-NBM, such as the medial septum (Ch1) and the diagonal band of Broca (Ch2 and $\mathrm{Ch} 3$ ), were excluded. Furthermore, we examined articles from the reference lists of the retrieved studies for additional eligible articles.

Study selection. Two authors (MN and IHP) independently screened the studies retrieved from the database search in two stages. First, all articles were screened based on titles and abstracts if electrical stimulation to the NBM was suggested. Non-original research articles were excluded. Second, full-text screening was performed to identify any data duplicates across studies. Finally, the included articles were classified according to the main outcome of the studies. These outcomes include the behavior, the secretion level of ACh, the effect on the CBF, NGF secretion, and brain glucose metabolism, and the effect on electrophysiological-related neuroplasticity.

Data extraction. Two authors (MN and IHP) independently extracted the data. The third author (TvL) decided about discrepancies in data extraction between the first two authors. The following data were extracted (1) general information: name of the first author, year of publication; (2) sample characteristics: animal model used, strain, age; (3) stimulation technique: details about the stimulation algorithm, timing and duration, intensity, pulse width, and frequency of stimulation; (4) description of experimental results qualitatively and, for studies with behavioral cognitive outcomes, quantitatively by extracting the mean and standard deviations (SDs) or standard errors (SE). Graphical data were measured using digital ruler software (Plot Digitizer).

Quality assessment. The quality of animal studies reporting the behavioral outcomes of NBM DBS was independently assessed by two authors (MN and IHP) using the SYRCLE Risk of Bias (RoB) criteria designed for animal studies ${ }^{96}$. The study quality was assessed for its internal validity by examining the risk of possible internal biases including performance bias, exclusion bias, detection bias, and selection bias. In addition, the reporting of electrode positioning verification and the complete reporting of the stimulation parameters were also checked. The RoB was rated high if the assessed methodology clearly introduced bias (see Supplementary Table 1, 2, and 3 for details). The RoB is low if the answer to the rating item was yes, high if the answer was no, or unclear if the explanation in the manuscript was missing.

Data synthesis. Data of all included studies were analyzed qualitatively and in addition quantitatively for behavioral outcomes. Meta-analysis was performed in animal studies which reported stimulation effects on cognitive tasks and involved comparisons with and without NBM DBS. The meta-analysis was performed using 
a random effect model by the metafor package in $\mathrm{R}$ (version 3.2.2) ${ }^{98}$. Random effect model was used to account for study-level heterogeneity. The standardized mean difference (SMD) of each outcome was calculated by subtracting the mean of the stimulation group to the mean of the sham control divided by the pooled SD of the two groups. SMD of each study was pooled to obtain an overall SMD and 95\% confidence interval. Heterogeneity was indicated by the I-squared test. Publication bias was analyzed by Egger's regression asymmetry test followed by fill-and-trim analysis to correct for publication bias ${ }^{99}$.

Received: 2 January 2021; Accepted: 24 May 2021

Published online: 03 June 2021

\section{References}

1. Kuhn, J. et al. Deep brain stimulation of the nucleus basalis of Meynert in Alzheimer's dementia. Mol. Psychiatry 20, 353-360 (2015).

2. Gratwicke, J. et al. Bilateral deep brain stimulation of the nucleus basalis of meynert for Parkinson disease dementia a randomized clinical trial. JAMA Neurol. 75, 169-178 (2018).

3. Gratwicke, J. et al. Bilateral nucleus basalis of Meynert deep brain stimulation for dementia with Lewy bodies: A randomised clinical trial. Brain Stimul. https://doi.org/10.1016/j.brs.2020.04.010 (2020).

4. Bohnen, N. I. et al. Cortical cholinergic function is more severely affected in parkinsonian dementia than in Alzheimer disease: An in vivo positron emission tomographic study. Arch. Neurol. 60, 1745-1748 (2003).

5. Bohnen, N. \& Albin, R. The cholinergic system in Parkinson's disease. Behav. Brain Res. 221, 564-573 (2011).

6. Gratwicke, J., Jahanshahi, M. \& Foltynie, T. Parkinson's disease dementia: A neural networks perspective. Brain 138, 1454-1476 (2015).

7. Gratwicke, J. et al. The nucleus basalis of Meynert: A new target for deep brain stimulation in dementia?. Neurosci. Biobehav. Rev. 37, 2676-2688 (2013).

8. Lv, Q. et al. Deep brain stimulation: A potential treatment for dementia in Alzheimer's disease (AD) and Parkinson's disease dementia (PDD). Front. Neurosci. 12, 360 (2018).

9. Barnikol, T. T. et al. Changes in apraxia after deep brain stimulation of the nucleus basalis Meynert in a patient with Parkinson dementia syndrome. Mov. Disord. 25, 1519-1520 (2010).

10. Freund, H.-J. et al. Cognitive functions in a patient with Parkinson-dementia syndrome undergoing deep brain stimulation. Arch. Neurol. 66, 781-785 (2009).

11. Montero-Pastor, A. et al. Nucleus basalis magnocellularis electrical stimulation facilitates two-way active avoidance retention, in rats. Brain Res. 900, 337-341 (2001).

12. Montero-Pastor, A. et al. Effects of electrical stimulation of the nucleus basalis on two-way active avoidance acquisition, retention, and retrieval. Behav. Brain Res. 154, 41-54 (2004).

13. Lee, J. E., Jeong, D. U., Lee, J., Chang, W. S. \& Chang, J. W. The effect of nucleus basalis magnocellularis deep brain stimulation on memory function in a rat model of dementia. BMC Neurol. 16, 6 (2016).

14. C, H. et al. The neuroprotective effect of deep brain stimulation at nucleus basalis of Meynert in transgenic mice with Alzheimer's disease. Brain Stimul. 12, 161-174 (2019).

15. Boix-Trelis, N., Vale-Martinez, A., Guillazo-Blanch, G., Costa-Miserachs, D. \& Marti-Nicolovius, M. Effects of nucleus basalis magnocellularis stimulation on a socially transmitted food preference and c-Fos expression. Learn. Mem. 13, 783-793 (2006).

16. Reed, A. et al. Cortical map plasticity improves learning but is not necessary for improved performance. Neuron 70, 121-131 (2011).

17. McLin, D. E. 3rd., Miasnikov, A. A. \& Weinberger, N. M. Induction of behavioral associative memory by stimulation of the nucleus basalis. Proc. Natl. Acad. Sci. U.S.A. 99, 4002-4007 (2002).

18. Weinberger, N. M., Miasnikov, A. A. \& Chen, J. C. Sensory memory consolidation observed: Increased specificity of detail over days. Neurobiol. Learn. Mem. 91, 273-286 (2009).

19. Miasnikov, A. A., Chen, J. C. \& Weinberger, N. M. Rapid induction of specific associative behavioral memory by stimulation of the nucleus basalis in the rat. Neurobiol. Learn. Mem. 86, 47-65 (2006).

20. Weinberger, N. M., Miasnikov, A. A. \& Chen, J. C. The level of cholinergic nucleus basalis activation controls the specificity of auditory associative memory. Neurobiol. Learn. Mem. 86, 270-285 (2006).

21. Miasnikov, A. A., Chen, J. C. \& Weinberger, N. M. Consolidation and long-term retention of an implanted behavioral memory. Neurobiol. Learn. Mem. 95, 286-295 (2011).

22. Miasnikov, A. A., Chen, J. C. \& Weinberger, N. M. Behavioral memory induced by stimulation of the nucleus basalis: Effects of contingency reversal. Neurobiol. Learn. Mem. 91, 298-309 (2009).

23. Liu, R. et al. Intermittent stimulation of the nucleus basalis of meynert improves working memory in adult monkeys. Curr. Biol. 27, 2640-2646 (2017).

24. Liu, R. et al. Intermittent stimulation in the nucleus basalis of meynert improves sustained attention in rhesus monkeys. Neuropharmacology 137, 202-210 (2018).

25. Miasnikov, A. A., Chen, J. C., Gross, N., Poytress, B. S. \& Weinberger, N. M. Motivationally neutral stimulation of the nucleus basalis induces specific behavioral memory. Neurobiol. Learn. Mem. 90, 125-137 (2008).

26. Miasnikov, A. A., Chen, J. C. \& Weinberger, N. M. Specific auditory memory induced by nucleus basalis stimulation depends on intrinsic acetylcholine. Neurobiol. Learn. Mem. 90, 443-454 (2008).

27. Avila, I. \& Lin, S. C. Motivational salience signal in the basal forebrain is coupled with faster and more precise decision speed. PLoS Biol. 12, e1001811 (2014).

28. Mayse, J. D., Nelson, G. M., Avila, I., Gallagher, M. \& Lin, S. C. Basal forebrain neuronal inhibition enables rapid behavioral stopping. Nat. Neurosci. https://doi.org/10.1038/nn.4110 (2015).

29. Koulousakis, P., Van Den Hove, D., Visser-Vandewalle, V. \& Sesia, T. Cognitive improvements after intermittent deep brain stimulation of the nucleus basalis of meynert in a transgenic rat model for Alzheimer's disease: A preliminary approach. J. Alzheimer's Dis. https://doi.org/10.3233/JAD-190919 (2020).

30. Casamenti, F., Deffenu, G., Abbamondi, A. L. \& Pepeu, G. Changes in cortical acetylcholine output induced by modulation of the nucleus basalis. Brain Res. Bull. 16, 689-695 (1986).

31. Rasmusson, D. D. et al. Frequency-dependent increase in cortical acetylcholine release evoked by stimulation of the nucleus basalis magnocellularis in the rat. Brain Res. 594, 150-154 (1992).

32. Kurosawa, M., Sato, A. \& Sato, Y. Well-maintained responses of acetylcholine release and blood flow in the cerebral cortex to focal electrical stimulation of the nucleus basalis of Meynert in aged rats. Neurosci. Lett. 100, 198-202 (1989). 
33. Kurosawa, M. et al. Stimulation of the nucleus basalis of Meynert increases acetylcholine release in the cerebral cortex in rats. Neurosci. Lett. 98, 45-50 (1989).

34. Lacombe, P., Sercombe, R., Vaucher, E. \& Seylaz, J. Reduced cortical vasodilatory response to stimulation of the nucleus basalis of Meynert in the aged rat and evidence for a control of the cerebral circulation. Ann. N. Y. Acad. Sci. 826, 410-415 (1997).

35. Uchida, S., Suzuki, A., Kagitani, F. \& Hotta, H. Effects of age on cholinergic vasodilation of cortical cerebral blood vessels in rats. Neurosci. Lett. 294, 109-112 (2000).

36. Uchida, S., Hotta, H., Misawa, H. \& Kawashima, K. Sustained subcutaneous infusion of nicotine enhances cholinergic vasodilation in the cerebral cortex induced by stimulation of the nucleus basalis of Meynert in rats. Eur. J. Pharmacol. 654, 235-240 (2011).

37. Biesold, D., Inanami, O., Sato, A. \& Sato, Y. Stimulation of the nucleus basalis of Meynert increases cerebral cortical blood flow in rats. Neurosci. Lett. 98, 39-44 (1989).

38. Takata, N. et al. Cerebral blood flow modulation by basal forebrain or whisker stimulation can occur independently of large cytosolic Ca2+ signaling in astrocytes. PLoS ONE 8, e66525 (2013).

39. Yan, J. \& Zhang, Y. Sound-guided shaping of the receptive field in the mouse auditory cortex by basal forebrain activation. Eur. J. Neurosci. 21, 563-576 (2005).

40. De Luna, P. et al. Basal forebrain activation enhances between-trial reliability of low-frequency local field potentials (LFP) and spiking activity in tree shrew primary visual cortex (V1). Brain Struct. Funct. 222, 4239-4252 (2017).

41. Berg, R. W. et al. Activation of nucleus basalis facilitates cortical control of a brain stem motor program. J. Neurophysiol. 94, 699-711 (2005).

42. Kilgard, M. P. \& Merzenich, M. Cortical map reorganization enabled by nucleus basalis activity. Science 279, 1714-1718 (1998).

43. Femano, P. A. et al. The effects of stimulation of substantia innominata and sensory receiving areas of the forebrain upon the activity of neurons within the amygdala of the anesthetized cat. Brain Res. 269, 119-132 (1983).

44. Inoue, M. et al. Cholinergic role in monkey dorsolateral prefrontal cortex during bar-press feeding behavior. Brain Res. 278, 185-194 (1983).

45. McLin, D. E. III. et al. The effects of electrical stimulation of the nucleus basalis on the electroencephalogram, heart rate, and respiration. Behav. Neurosci. 116, 795-806 (2002).

46. McLin, D. E. 3rd., Miasnikov, A. A. \& Weinberger, N. M. CS-specific gamma, theta, and alpha EEG activity detected in stimulus generalization following induction of behavioral memory by stimulation of the nucleus basalis. Neurobiol. Learn. Mem. 79, 152-176 (2003).

47. Metherate, R. \& Ashe, J. H. Nucleus basalis stimulation facilitates thalamocortical synaptic transmission in the rat auditory cortex. Synapse 14, 132-143 (1993).

48. Howard, M. A. 3rd. et al. Physiologic effects of nucleus basalis magnocellularis stimulation on rat barrel cortex neurons. Exp. Brain Res. 102, 21-33 (1994).

49. Kuo, M.-C., Rasmusson, D. D. \& Dringenberg, H. C. Input-selective potentiation and rebalancing of primary sensory cortex afferents by endogenous acetylcholine. Neuroscience 163, 430-441 (2009).

50. Metherate, R. \& Ashe, J. H. Ionic flux contributions to neocortical slow waves and nucleus basalis-mediated activation: whole-cell recordings in vivo. J. Neurosci. 13, 5312-5323 (1993).

51. Bjordahl, T. S., Dimyan, M. A. \& Weinberger, N. M. Induction of long-term receptive field plasticity in the auditory cortex of the waking guinea pig by stimulation of the nucleus basalis. Behav. Neurosci. 112, 467-479 (1998).

52. Miasnikov, A. A., McLin, D. 3rd. \& Weinberger, N. M. Muscarinic dependence of nucleus basalis induced conditioned receptive field plasticity. NeuroReport 12, 1537-1542 (2001).

53. Suga, N. \& Ma, X. Multiparametric corticofugal modulation and plasticity in the auditory system. Nat. Rev. Neurosci. 4, 783-794 (2003).

54. Zhang, Y., Hakes, J. J., Bonfield, S. P. \& Yan, J. Corticofugal feedback for auditory midbrain plasticity elicited by tones and electrical stimulation of basal forebrain in mice. Eur. J. Neurosci. 22, 871-879 (2005).

55. Bieszczad, K. M. B., Miasnikov, A. A. \& Weinberger, N. M. Remodeling sensory cortical maps implants specific behavioral memory. Neuroscience 246, 40-51 (2013).

56. Goard, M. \& Dan, Y. Basal forebrain activation enhances cortical coding of natural scenes. Nat. Neurosci. 12, 1444-1449 (2009).

57. Chen, N. et al. Nucleus basalis-enabled stimulus-specific plasticity in the visual cortex is mediated by astrocytes. Proc. Natl. Acad. Sci. U. S. A. 109, E2832-E2841 (2012).

58. Turnbull, I. M., McGeer, P. L., Beattie, L., Calne, D. \& Pate, B. Stimulation of the basal nucleus of Meynert in senile dementia of Alzheimer's type A preliminary report. Appl. Neurophysiol. 48, 216-221 (1985).

59. Noreik, M. et al. Changes in nutritional status after deep brain stimulation of the nucleus basalis of meynert in Alzheimer's diseaseresults of a phase I study. J. Nutr. Health Aging 19, 812-818 (2015).

60. Dürschmid, S. et al. Deep brain stimulation of the nucleus basalis of Meynert attenuates early EEG components associated with defective sensory gating in patients with Alzheimer disease-a two-case study. Eur. J. Neurosci. https://doi.org/10.1111/ejn.13749 (2017).

61. Maltête, D. et al. Nucleus basalis of meynert stimulation for lewy body dementia: A phase I randomized clinical trial. Neurology https://doi.org/10.1212/WNL.0000000000011227 (2020).

62. Nombela, C. et al. Simultaneous stimulation of the globus pallidus interna and the nucleus basalis of meynert in the Parkinsondementia syndrome. Dement. Geriatr. Cogn. Disord. 47, 19-28 (2019).

63. Richter, N. et al. Effect of cholinergic treatment depends on cholinergic integrity in early Alzheimer's disease. Brain https://doi. org/10.1093/brain/awx356 (2018).

64. Meng, D., Li, X., Bauer, M., Taylor, J. P. \& Auer, D. P. Altered nucleus basalis connectivity predicts treatment response in mild cognitive impairment. Radiology https://doi.org/10.1148/radiol.2018180092 (2018).

65. Teipel, S. J. et al. Predictors of cognitive decline and treatment response in a clinical trial on suspected prodromal Alzheimer's disease. Neuropharmacology https://doi.org/10.1016/j.neuropharm.2016.02.005 (2016).

66. Panov, F. et al. Intraoperative electrocorticography for physiological research in movement disorders: Principles and experience in 200 cases. J. Neurosurg. 126, 122-131 (2017).

67. Parastarfeizabadi, M. \& Kouzani, A. Z. Advances in closed-loop deep brain stimulation devices. J. Neuroeng. Rehabil. https://doi. org/10.1186/s12984-017-0295-1 (2017).

68. Kuo, C. H., White-Dzuro, G. A. \& Ko, A. L. Approaches to closed-loop deep brain stimulation for movement disorders. Neurosurg. Focus https://doi.org/10.3171/2018.5.FOCUS18173 (2018).

69. Hell, F., Palleis, C., Mehrkens, J. H., Koeglsperger, T. \& Bötzel, K. Deep brain stimulation programming 2.0: Future perspectives for target identification and adaptive closed loop stimulation. Front. Neurol. https://doi.org/10.3389/fneur.2019.00314 (2019).

70. Habets, J. G. V. et al. An update on adaptive deep brain stimulation in Parkinson's disease. Mov. Disord. https://doi.org/10.1002/ mds.115 (2018).

71. Swann, N. C. et al. Adaptive deep brain stimulation for Parkinson's disease using motor cortex sensing. J. Neural Eng. https://doi. org/10.1088/1741-2552/aabc9b (2018).

72. Kibleur, A. \& David, O. Electroencephalographic read-outs of the modulation of cortical network activity by deep brain stimulation. Bioelectron. Med. https://doi.org/10.1186/s42234-018-0003-x (2018). 
73. Litvak, V., Florin, E., Tamás, G., Groppa, S. \& Muthuraman, M. EEG and MEG primers for tracking DBS network effects. Neuroimage https://doi.org/10.1016/j.neuroimage.2020.117447 (2021).

74. Nandi, D., Jenkinson, N., Stein, J. \& Aziz, T. The pedunculopontine nucleus in Parkinson’s disease: Primate studies. Br. J. Neurosurg. 22(Suppl 1), S4-8 (2008).

75. Lozano, A. M. et al. Deep brain stimulation: Current challenges and future directions. Nat. Rev. Neurol. https://doi.org/10.1038/ s41582-018-0128-2 (2019).

76. Chiken, S. \& Nambu, A. Disrupting neuronal transmission: Mechanism of DBS?. Front. Syst. Neurosci. https://doi.org/10.3389/ fnsys.2014.00033 (2014).

77. Disney, A. A. \& Robert, J. S. Translational implications of the anatomical nonequivalence of functionally equivalent cholinergic circuit motifs. Proc. Natl. Acad. Sci. U.S.A. https://doi.org/10.1073/pnas.1902280116 (2019).

78. Coppola, J. J. \& Disney, A. A. Is there a canonical cortical circuit for the cholinergic system? Anatomical differences across common model systems. Front. Neural Circ. https://doi.org/10.3389/fncir.2018.00008 (2018).

79. Liu, A. K. L., Chang, R.C.-C., Pearce, R. K. B. \& Gentleman, S. M. Nucleus basalis of Meynert revisited: Anatomy, history and differential involvement in Alzheimer's and Parkinson's disease. Acta Neuropathol. 129, 527-540 (2015).

80. Mesulam, M. M. \& Geula, C. Nucleus basalis (Ch4) and cortical cholinergic innervation in the human brain: Observations based on the distribution of acetylcholinesterase and choline acetyltransferase. J. Comp. Neurol. 275, 216-240 (1988)

81. Mesulam, M. M., Mufson, E. J., Levey, I. \& Wainer, B. H. Cholinergic innervation of cortex by the basal forebrain: cytochemistry and cortical connections of the septal area, diagonal band nuclei, nucleus basalis (substantia innominata), and hypothalamus in the rhesus monkey. J. Comp. Neurol. 214, 170-197 (1983).

82. Bloem, B. et al. Topographic mapping between basal forebrain cholinergic neurons and the medial prefrontal cortex in mice. J. Neurosci. 34, 16234-16246 (2014).

83. Kilimann, I. et al. Subregional basal forebrain atrophy in alzheimer's disease: A multicenter study. J. Alzheimer's Dis. 40, 687-700 (2014).

84. Ray, N. J. et al. In vivo cholinergic basal forebrain atrophy predicts cognitive decline in de novo Parkinson's disease. Brain 141, $165-176(2018)$.

85. Ozen Irmak, S. \& de Lecea, L. Basal forebrain cholinergic modulation of sleep transitions. Sleep https://doi.org/10.5665/sleep.4246 (2014).

86. Dudai, Y., Karni, A. \& Born, J. The consolidation and transformation of memory. Neuron https://doi.org/10.1016/j.neuron.2015. 09.004 (2015).

87. Martinez, V. \& Sarter, M. Lateralized attentional functions of cortical cholinergic inputs. Behav. Neurosci. https://doi.org/10.1037/ 0735-7044.118.5.984 (2004)

88. España, R. A., Reis, K. M., Valentino, R. J. \& Berridge, C. W. Organization of hypocretin/orexin efferents to locus coeruleus and basal forebrain arousal-related structures. J. Comp. Neurol. 481, 160-178 (2005).

89. Demeter, E., Hernandez-Garcia, L., Sarter, M. \& Lustig, C. Challenges to attention: A continuous arterial spin labeling (ASL) study of the effects of distraction on sustained attention. Neuroimage https://doi.org/10.1016/j.neuroimage.2010.09.026 (2011).

90. Deprez, M. et al. An evaluation of the effect of pulse-shape on grey and white matter stimulation in the rat brain. Sci. Rep. https:// doi.org/10.1038/s41598-017-19023-0 (2018).

91. Hofmann, L., Ebert, M., Tass, P. A. \& Hauptmann, C. Modified pulse shapes for effective neural stimulation. Front. Neuroeng. https://doi.org/10.3389/fneng.2011.00009 (2011).

92. Schor, J. S. \& Nelson, A. B. Multiple stimulation parameters influence efficacy of deep brain stimulation in parkinsonian mice. J. Clin. Invest. https://doi.org/10.1172/JCI122390 (2019).

93. Anderson, C. J., Anderson, D. N., Pulst, S. M., Butson, C. R. \& Dorval, A. D. Neural selectivity, efficiency, and dose equivalence in deep brain stimulation through pulse width tuning and segmented electrodes. Brain Stimul. https://doi.org/10.1016/j.brs.2020. $03.017(2020)$.

94. Steigerwald, F. et al. Pulse duration settings in subthalamic stimulation for Parkinson's disease. Mov. Disord. https://doi.org/10. $1002 / \mathrm{mds} .27238$ (2018).

95. Bentley, J. N. et al. Subcortical intermittent theta-burst stimulation (iTBS) increases theta-power in dorsolateral prefrontal cortex (DLPFC). Front. Neurosci. https://doi.org/10.3389/fnins.2020.00041 (2020).

96. Hooijmans, C. R. et al. SYRCLE's risk of bias tool for animal studies. BMC Med. Res. Methodol. 14, 43 (2014).

97. de Vries, R. B. M. et al. A protocol format for the preparation, registration and publication of systematic reviews of animal intervention studies. Evid.-Based Preclin. Med. 2, e00007 (2015).

98. Viechtbauer, W. Conducting meta-analyses in R with the metafor. J. Stat. Softw. (2010).

99. Duval, S. \& Tweedie, R. A nonparametric, "Trim and Fill" method of accounting for publication bias in meta-analysis. J. Am. Stat. Assoc. 95, 89-98 (2000).

\section{Author contributions}

M.N. and I.H.C.H.M.P. contributed to drafting the manuscript, study design, data analysis and statistical analysis. T.v.L. contributed to drafting the study design and manuscript, interpretation of the collected data, and as an independent reviewer to working through each phase of screening, eligibility and inclusion in meta-analysis.

\section{Competing interests}

T.v.L. has received research support from the Weston Brain Institute, speaker fees from Britannia, AbbVie and Medtronic, and is on the advisory boards of LTI and Neuroderm. M.N. and I.H.C.H.M.P. declare no potential conflict of interest.

\section{Additional information}

Supplementary Information The online version contains supplementary material available at https:/doi.org/ 10.1038/s41598-021-91391-0.

Correspondence and requests for materials should be addressed to M.N.

Reprints and permissions information is available at www.nature.com/reprints.

Publisher's note Springer Nature remains neutral with regard to jurisdictional claims in published maps and institutional affiliations. 
(c) (i) Open Access This article is licensed under a Creative Commons Attribution 4.0 International cc) License, which permits use, sharing, adaptation, distribution and reproduction in any medium or format, as long as you give appropriate credit to the original author(s) and the source, provide a link to the Creative Commons licence, and indicate if changes were made. The images or other third party material in this article are included in the article's Creative Commons licence, unless indicated otherwise in a credit line to the material. If material is not included in the article's Creative Commons licence and your intended use is not permitted by statutory regulation or exceeds the permitted use, you will need to obtain permission directly from the copyright holder. To view a copy of this licence, visit http://creativecommons.org/licenses/by/4.0/.

(C) The Author(s) 2021 